\title{
How the Discourse of Urban Smart Mobility Portrays the Role of Automobility after 'The End of Car Ownership'
}

\author{
Arto Lanamäki \\ University of Vaasa \\ arto.lanamaki@univaasa.fi
}

\begin{abstract}
The slogan "the end of car ownership" (TEoCO) occurs regularly in the discourse of urban smart mobility. In this article, I examine TEOCO as a micronarrative used for agenda framing purposes. I situate the discourse within the theory of urban fabrics, to argue how cities need to fight car dependence. The TEOCO slogan appears as a seemingly powerful policy and marketing device. The slogan establishes private car use - and the negative externalities of automobility - as the baseline comparison for new digital mobility services. Urban smart mobility's promise to eradicate car ownership but not cars per se may be a reinforcement of car dependence. Smart mobility cannot relieve cities from car dependence, because the most lucrative business opportunities in mobility reside in automobility.
\end{abstract}

\section{Introduction}

The concept of smart mobility emerged after the turn of the millennium [1], sparking a wide range of research activities around the world [2,3]. The slogan "the end of car ownership" (TEOCO) has often been situated in the smart mobility discourse. TEoCO has turned into a ubiquitous slogan, used by various ridesharing, carsharing, robocar, and Mobility-as-aService (MaaS) companies, as well as featured in popular media.

In this paper, I examine how the "end of car ownership" slogan has been used in various contexts over the years. I identify what this discourse portrays as the cause to this end - and what will occur after the end. The research question is: "What is the role of automobility in the future(s) envisioned by the "the end of car ownership' slogan?"

The paper is structured as follows. In the next section, I present the urban fabrics theory as a framework to situate the projections of TEoCO statements. In section three, I present the methodological premises. In section 4 , I offer an analysis of seven selected occurrences of TEoCO. I discuss the findings, and finally conclude by outlining the implications for practice and for IS research.

\section{Related work}

\subsection{Urban smart mobility and IS research}

Socio-technical concerns have always been central to Information Systems research [4]. As IS researchers, we pay attention not only to technologies per se, but also to the contexts where technologies are developed, implemented, adopted, appropriated, contested, and repurposed. In the early days of our field, mainframes in large corporations were the dominant technology-in-context [5]. In more recent times, information technology has become ubiquitous in virtually all social contexts and thus has created abundant research opportunities. Markus \& Nan [6] define "Theorizing the role of the digital in the lives of individuals, organizations, and society" as "the mission of the IS field - our very raison d'être" (p. 66).

Many IS researchers are now addressing challenges related to urban mobility [7-9]. After IS researchers entered this area previously occupied by urban geographers, city planners and transport engineers, the framing has most often been in the automotive industry and intelligent transport systems [10-12]. The framing is assumptively driven by available research funding, provided by the automotive industry directly or indirectly. Clarke et al. [13] recently identified that "IS researchers mostly adopt the perspective of one of the stakeholders ..., commonly that of the sponsor of the information system that is in focus."

\subsection{Car dependence and the theory of urban fabrics}

The concept of automobile dependence was first outlined by Australian professors Peter Newman and Jeff Kenworthy in their 1989 book "Cities and 
Automobile Dependence" [14]. They provided a comparative study of 32 major cities in four continents, concluding that low-density cities are often associated with car dependence. Sprawling US cities like Los Angeles and Houston are especially dependent on car use. In this line, Cervero [15] equates car ownership to "a subscription fee paid to fully participate in American life." (p. 410).

Other researchers have similarly identified the dominance of automobility. Urry [16] defined automobility as a system "that coerces people into an intense flexibility" (p. 28). According to Urry, automobility has been the enabler of various social institutions, including "suburban housing, oil companies, out-of-town shopping centres" (p. 32). Once those institutions established, it has proven difficult to dissolve their locked-in interdependencies. On the contrary, the rise of automobility has required building more infrastructure, enabling ever more automobility. Cars require space: roads, intersections, junctions, parking facilities, and wider highways [17, 18]. However, the improved infrastructure has provided only temporary relief for large cities. For example, Hymel [19] identified that expanding road capacity help reduce congestion for only five years on average; the induced demand resummons the congestion. There is now a scientific consensus that building more and wider roads is not the permanent solution to congestion; instead, many cities are removing their freeways [20].

Mattioli et al. [18] identified five constituting factors for the political economy of car dependence: 1) the automotive industry; 2) the provision of car infrastructure; 3) the political economy of urban sprawl; 4) the provision of public transport; and 5) cultures of car consumption. Gössling et al. [21] calculated a cost-benefit analysis for automobility, cycling and walking. Cycling and walking provide benefits worth of $0,18 €$ and $0,37 €$ per kilometer respectively. Automobility, on the other hand, has significant external costs of $0,11 €$ per kilometer. Gössling et al. estimate that the cost of automobility is about 500 billion euros each year in the European Union, therefore being "heavily subsidized" (p. 72).

After the publication the 1999 book "Sustainability and Cities: Overcoming Automobile Dependency," [22] the authors Newman and Kenworthy have collaborated with various Finnish urban planners. Perhaps their most significant collaboration has been around the theory of urban fabrics, which emerged when Newman and Kenworthy's academic work was applied with urban planner Leo Kosonen from the city of Kuopio, Finland [23]. This work has had much relevance in the practice of urban planning in Finland and elsewhere [24-26].
The urban fabrics theory [23, 27] views cities through three overlapping 'fabrics': the walking city, transit city, and automobile city. Based on a principle of the daily one hour travel time budget, which has been established in urban planning and transport economics research [28, 29], the theory argues that "urban fabrics of the cities grow to be 'one hour wide' based on the speed at which people can move in them." The walking city is about $1-2 \mathrm{~km}$ wide, with moving speeds of about 3-4 km/h. Newman et al. [23] list Kraków, Barcelona, Ho Chi Minh City, Mumbai, and Hong Kong as traditional walking cities. The transit city is where people commute largely using trains, trams and subways - for example London, Paris, and New York. Finally, automobility-dominated cities emerged after 1950s, allowing travel speeds of 50-80 $\mathrm{km} / \mathrm{h}$ and daily commuting distances of up to 80 kilometers. Automobility enables low-density settling, which then dictates people into automobility $[18,30]$.

The theory of urban fabrics is particularly wellsuited lens to analyze cities where automobility has gained a strong dominance. Through mapping the overlapping fabrics, walkability and public transportation can be improved - thus car dependence be reduced.

\section{Methodological notes}

This article is a reflexive essay [31] on the occurrences of the slogan 'The End of Car Ownership' (TEoCO). In terms of genre and method, I have drawn inspiration from the problematizing review [32] and the narrative review. There is a die-hard belief in IS research that replicable systematic reviews represent the gold standard and the best way to gather and synthesize published work [33]. However, various accounts in different fields narrative and problematizing approaches are equally valid - they just service different purposes [34-36].

In 2015, the Journal of Information Technology published a debate initiated by Boell and CecezKecmanovic [35] concerning systematic reviews. In one of the replies, Schultze [37] outlined a continuum with 'systematic literature reviews' and 'interpretive literature reviews' as polar opposites. 'Interpretive' is here synonymous to 'problematizing.' Citing Alvesson and Sandberg [38], Schultze defines how interpretive or problematizing reviews "do not depend on an exhaustive review of all the literature for their believability," but instead aim to provide a "profound and critical analysis," "by unearthing inconsistent theoretical assumptions." (p. 181)

Alvesson and Sandberg [32] present four key characteristics for problematizing reviews. These are 1 ) the ideal of reflexivity, 2) reading more broadly but 
selectively, 3) not accumulating but problematizing, and 4) the concept of 'less is more'.

I also derive influence from Lakoff [39] and Irvin [40] for their ideas on persuasive language use and framing. I treat the TEoCO phrase as a micronarrative doing the work of agenda framing [40].

On a personal note, this paper begun from my own wondering (cf. [41]), after having read about "the end of car ownership" in various contexts. I came to contemplate about this proposed "end," whether it means a beginning for something else - what? Some of the occurrences of TEoCO, including Zipcar and MaaS Global, came from my early readings in 2019 or earlier. The other occurrences I identified using a phrase search I conducted in summer 2020 using Google Search and Google Scholar. In the next section, I present the results of this analysis.

\section{Findings: A Selected History of TEoCO}

One of the first instances of TEoCO as a marketing slogan occurred in early 2000s, when an American car-sharing company Zipcar used it. The company became a poster child of access-based and collaborative consumption, receiving much attention in Gansky's 2010 book "The Mesh: Why the Future of Business is Sharing" [42] and Botsman and Rogers' 2011 "What's Mine is Yours" [43]. Zipcar adopted a green image and the advertising slogan "Each and every Zipcar takes 15 personally-owned vehicles off the road." Interestingly, the environmental-minded claims did not often translate into action. Bardhi \& Eckhardt's 2012 paper [44] presented an interviewbased study with 40 Zipcar clients. Contrary to expectations, they found that "rejecting car ownership for ideological reasons ... was not the case" (p. 887). They conclude that "in contrast to the altruistic model of sharing, the anonymous, market-mediated type of access does not produce a sense of joint or perceived ownership and is not prosocial but instead is primarily guided by self-serving and utilitarian motivation and negative reciprocity toward the accessed object, firm, and other consumers." (p. 895)

In his critical book against the corporate sharing economy, Slee [45] argues that by pronouncing TEoCO, Zipcar established the private car as its only baseline comparison (p. 47). As automobility has various bad consequences especially at large scale, this baseline comparison is a convenient choice. When

\footnotetext{
1 Various versions are available online, e.g. https://www.prorautatie.fi/uploads/1/2/7/0/127005085/hietanen_29 112019.pdf; http://www.tut.fi/verne/aineisto/B1_Hietanen.pdf; https://www.maasmarket.com/sites/default/files/SAMPO\%20HIETANEN\%20AFTE
}

choosing the baseline correctly, it is possible to make almost any mobility service look like a solution to fighting climate change.

\begin{tabular}{|c|c|c|}
\hline Occurrence & Problem (End) & $\begin{array}{l}\text { Solution (New } \\
\text { Beginning) }\end{array}$ \\
\hline $\begin{array}{l}\text { ZipCar } \text { (early } \\
2000 s, \text { referenced } \\
\text { in early 2010s } \\
\text { sharing economy } \\
\text { literature }[42,43])\end{array}$ & $\begin{array}{l}\text { Congestion, } \\
\text { other } \\
\text { environmental } \\
\text { concerns }\end{array}$ & Car sharing \\
\hline $\begin{array}{l}\text { Access-based } \\
\text { consumption [46], } \\
\text { e.g. Mercedes } \\
\text { Benz (late 1990s) }\end{array}$ & $\begin{array}{l}\text { Upfront costs } \\
\text { and } \\
\text { inconvenience } \\
\text { of car ownership }\end{array}$ & $\begin{array}{l}\text { Car leasing, } \\
\text { customer lock- } \\
\text { in }\end{array}$ \\
\hline \begin{tabular}{lr} 
Travis & \multicolumn{2}{r}{ Kalanick, } \\
CEO of & Uber \\
(May 2014 & {$[47]$,} \\
February & 2015 \\
{$[48]$ ) } & \\
\end{tabular} & $\begin{array}{l}\text { Costs of } \\
\text { ownership, costs } \\
\text { of human driver }\end{array}$ & $\begin{array}{l}\text { Autonomous } \\
\text { vehicles }\end{array}$ \\
\hline $\begin{array}{l}\text { John Zimmer, } \\
\text { CEO of Lyft } \\
\text { (September, 2016) } \\
\text { [49] }\end{array}$ & $\begin{array}{l}\text { Allocation of } \\
\text { urban space to } \\
\text { parking, traffic, } \\
\text { pollution }\end{array}$ & $\begin{array}{l}\text { Autonomous } \\
\text { fleets "below } \\
\text { the cost of car } \\
\text { ownership", } \\
\text { TEoCO in } \\
\text { major US cities } \\
\text { by } 2025\end{array}$ \\
\hline $\begin{array}{ll}\text { Wall } & \text { Street } \\
\text { Journal } & \text { (June, } \\
2017)[50] & \end{array}$ & $\begin{array}{l}\text { Parking, } \\
\text { congestion, loss } \\
\text { of time in } \\
\text { commuting }\end{array}$ & $\begin{array}{l}\text { Ridesharing, } \\
\text { dense } \\
\text { urbanization, } \\
\text { self-driving } \\
\text { vehicles, } \\
\text { renting out } \\
\text { vehicles }\end{array}$ \\
\hline $\begin{array}{l}\text { Sampo Hietanen, } \\
\text { CEO of } \\
\text { Global / } \\
\text { (Companim } \\
\text { deck 2017-2019) }\end{array}$ & $\begin{array}{l}\text { High cost of } \\
\text { owning and } \\
\text { maintaining a } \\
\text { car, low use rate } \\
\text { of private cars, } \\
\text { inconvenience } \\
\text { of public } \\
\text { transportation } \\
\text { timetables and } \\
\text { locations }\end{array}$ & $\begin{array}{l}\text { Integrated } \\
\text { MaaS service } \\
\text { providing } \\
\text { seamless } \\
\text { access to all } \\
\text { modes of } \\
\text { transportation }\end{array}$ \\
\hline $\begin{array}{l}\text { Dan Ammann, } \\
\text { CEO of Cruise } \\
\text { (December, 2019) } \\
\text { [51] }\end{array}$ & $\begin{array}{l}\text { Fossil fuels, } \\
\text { pollution, } \\
\text { congestion, fatal } \\
\text { traffic accidents }\end{array}$ & $\begin{array}{l}\text { Electric, self- } \\
\text { driving cars } \\
\text { built for ride- } \\
\text { sharing }\end{array}$ \\
\hline
\end{tabular}

Table 1: Seven selected occurrences of 'TEoCO'

In his 2000 book The Age of Access [46], Rifkin outlined how access has come to triumph over ownership. One of his main examples comes from automobility, which he sees slowly transforming from

RNOON.pdf;

http://media.bccd.dk/media/Events/2017/Sustainable_Innovation/ MaaS_Sampo_Hietanen.pdf 
a product to a service. Rifkin writes that the "metamorphosis from something they own to something they lease is a sign of the dramatic changes taking place in the organizing of economic relationships." Rifkin quotes Helmut Werner, thenCEO of Mercedes-Benz, that "[We] don't want to just sell another car, but rather offer a complete package of transportation services" [46]. From the company's perspective, leasing has more business potential than a one-time sales event, due to a leasing contract establishes a long-term bond to the customer.

During 2014 and 2015, then-CEO of Uber, Travis Kalanick, made statements that they will end the need for car ownership [47, 48]. Kalanick stated in 2014 that the autonomous vehicles will eventually bring about the end of car ownership by being a more costeffective alternative. It would also cut the cost of a human driver: "The reason Uber could be expensive is because you're not just paying for the car, you're paying for the other dude in the car.... You basically bring the cost below the cost of ownership for everybody, and then car ownership goes away" [47].

Uber's competitor Lyft has made similar comments about TEoCO. Similarly associating TEoCO to the arrival of autonomous vehicles, Lyft CEO John Zimmer has claimed that Lyft's future autonomous fleet will provide mobility "below the cost of car ownership" [49]. Zimmer also gave a year when TEoCO will happen in major US cities: by 2025.

TEoCO has been discussed in various media outlets over the years. The Wall Street Journal writer Tim Higgins wrote a lengthy article titled "The End of Car Ownership" in June 2017 [50]. In this piece, Higgins described various problems and inconveniences related to car ownership such as the need for parking space, congestion, and the time lost while commuting. Higgins listed a variety of solutions such as ridesharing and self-driving vehicles, that will eventually make TEoCO a reality.

MaaS Global, the Finnish company behind the mobility-as-a-service app Whim, has regularly used the title "Mobility as a Service - The End of Car Ownership?" in its slide deck over the years. The promise is that MaaS provides the convenience of a private car by offering a seamless access to public transportation, city bikes, taxi, electric scooters, and other mobility options [52]. MaaS is the digital layer that combines already existing mobility modes in bundles and pay-as-you-go offerings [53].

The MaaS Global slide deck defines its global market size to be 10 trillion dollars. It is quite easy to guess that amount of money does not come from the promotion of walking and bicycling. Due to public transit is highly subsidized with taxpayers' money [54, 55], the business potential is most probably not in public transportation either. The company's CEO Sampo Hietanen argues [56] that "the profitable part [of MaaS] is having access to a car on weekend, otherwise MaaS is just a utility service." The business potential of MaaS is in turning a high-spending car owner into a high-spending weekend driver.

TEoCO slogan continues to occur in various contexts of new business and innovation. In December 2019, the former President of General Motors, Dan Ammann, who is now the head of the self-driving car company Cruise, made a statement about TEoCO. Ammann made a slightly controversial public comment about his former employer GM (which is the main funder of Cruise), and other legacy car manufactures. [51] Amman wrote that the automotive industry is "powered by fossil fuels that will pollute our air, ... congest our cities to the point of inciting rage in its users. Its human operators will be fallible, killing 40,000 Americans - and more than a million people around the world - every year." Ammann claimed that "the best cure" to these problems is "electric, self-driving vehicles purpose built for ridesharing." In other words, the version of TEoCO that Cruise promises is one retaining the dominance of automobiles in cities.

\section{Discussion}

In this paper I have examined the often-occurring slogan of "the end of car ownership" (TEoCO) within the urban mobility discourse. In this section, I reflect on these various contexts where TEoCO claims have occurred.

My first observation concerns the mobility modes after TEoCO. Except for MaaS, six out of seven occurrences of TEoCO promise to replace car ownership by an upgraded version of automobility. While the TEoCO slogan is often complimented with mentions of automobility's negative externalities pollution, occupying urban space, congestion TEoCO is therefore mostly a pro-automobility phrase. The pronounced end of car ownership promises the end of "bad automobility" replaced by "better automobility." The discourse provides a variety of these automobility improvements: leasing, ondemand, pay-per-use, sharing, and automation. In this way, TEoCO and the whole smart mobility discourse fits Urry's [16] claim that the discourse on the future of mobility tends to be dominated by automobilitycentric linear thinking. Urry states that the "real challenge is how to move to a different pattern involving a more or less complete break with the current car system." (p. 33). The theory of urban fabrics, presented in section 2 , could provide a more sustainable, balanced, and lively model for cities. 
The case of MaaS is interesting here. In the Finnish context where MaaS originated, the initial motivation for the government's agenda was to facilitate new export businesses. For example, the Finnish Ministry of Transport and Communication's (LVM) October 2015 press release defined MaaS as "a Government key project on building a growth environment for digital business" [57]. Much later, the MaaS agenda has expanded into sustainability arguments. For example, during Finland's Presidency of the Council of the EU (June 2019 - December 2019), MaaS has risen into an important Europeanlevel policy issue for sustainable transportation. ${ }^{2}$ The sustainability goal is mostly grounded on the assumed potential of MaaS to reduce car ownership [58, 59]. However, there may be a contradiction between the sustainability claims and the hunger for a $\$ 10 \mathrm{~T}$ global MaaS market. The profitable part of MaaS money is in automobility [56]. Regardless of promises of better automobility - electric, automated, and shared [60] it is doubtful that automobility can ever be as sustainable as walking and public transportation.

Various MaaS experiments have been trialed around the world [61, 62], but MaaS is still more a utopian concept rather than an existing reality. As the MaaS definition states, MaaS does not add new capacity or infrastructure. Instead, it integrates existing services and provides it as one package. Therefore, the possible reduction of car ownership is attributed to shifting cultural practices and attitudes [52]. The potential of MaaS to achieve this mass behavior change is still unproven [63].

TEoCO has been used as a phrase now for more than two decades. That shows that the slogan has persistence and applicability across various contexts. The variety of these companies demonstrates that the concept has wide appeal. Some of the that appeal may be in its framing power: setting the most effective baseline comparison for marketing and public policy purposes [45]. For example, it was not before 2019 when Uber filed its Initial Public Offering document when it confessed viewing public transportation as its competitor [64]. Before that, the general perception was that Uber was only competing against car ownership [47]. The sharing economy discourse, in particular, masqueraded itself as a solution to trafficrelated problems (e.g., [65]).

\section{Conclusion}

\subsection{Practical implications}

Cities are at the core of climate change mitigation and strategic low-carbon initiatives [66]. Automobility is a central source of carbon emissions and pollution [67], and a significant burden to our societies [21].

In this paper, I have studied the regularly occurring phrase 'The End of Car Ownership' (TEoCO). I argued that the phase is deliberately vague, allowing interpretive flexibility for the concept to be used to serve different purposes. The phrase carries promise of sustainability, while still strongly oriented in promoting (a better version of) automobility.

The analysis shows that while the TEoCO slogan is often complimented with mentions of automobility's negative externalities - pollution, occupying urban space, congestion - TEoCO frames ownership as the main problem, not automobility per se. Therefore, TEoCO can be classified as a proautomobility concept.

It is worthwhile contemplating how the Covid-19 pandemic will affect the role of automobility in cities, and the ownership of cars. On one hand, the lockdowns have reportedly reduced car traffic and consequently improved the air quality in many cities such as Delhi, Sao Paulo, and Bogota [68]. People in various parts of the world are contemplating if it is possible to retain the car-free city after the pandemic is over [69]. On the other hand, various news outlets have reported increased car rentals and booming usedcar sales (e.g., [70]).

Perhaps some parts of the world need strategies targeting car ownership (TEoCO), but a much more urgent need is for TEoCD: the end of car dependence. In fact, Newman, the co-founder of the urban fabrics theory, stated almost two decades ago that "I have no problem with cars and car ownership... car dependence is the problem. If you have to have a car, whether you can afford it or not, that is the problem." ([71], p. 153).

Looking at the state of the world, it seems improbable that an actual end of car ownership is coming any time soon. The total amount of cars worldwide is well over one billion. Regardless that new alternatives for mobility are emerging, many people will keep on driving their own cars - some because they have to, others because they want to [72].

2 https://www.consilium.europa.eu/en/councileu/configurations/tte/ (Accessed 11 October 2019) 


\subsection{Implications for IS research}

Through the abundant ubiquity of information technology in contemporary societies [73], IS researchers have come to tackle challenges related to urban mobility [7-9]. After IS researchers entered this area previously occupied by urban geographers, city planners and transport engineers, the framing has most often been in the automotive industry and intelligent transport systems [10-12]. Clarke et al. [13] recently analyzed that IS researchers tend to take a single perspective in their research, "commonly that of the sponsor of the information system that is in focus." This raises concern whether IS research is making the world a better place holistically. Are we improving the traffic, safety, and living conditions in cities, or are we reinforcing existing inequalities? [74, 75]

I call for IS researchers to contemplate how our research could tackle car dependence in cities [18, 23]. Applying the theory of urban fabrics $[23,27]$ may be useful in finding a balanced solution for urban mobility problems. Let us make our research smart by seriously acknowledging the wider contexts in which urban mobility occurs.

There are various limitations to this present study. Future research could investigate TEoCO and other phrases and slogans used in different contexts, for instance by using larger samples. Various technological developments are dependent on a favorable public discourse, and on political support. Therefore, an interesting future research avenue is to study how sloganeering and micronarratives shape public opinion (e.g., [40]).

\section{Acknowledgements}

I am thankful for the editor and the reviewers for helpful feedback. I would also like to thank Miloš Mladenović and Albert Gragera for useful discussions around this topic. A small portion of this paper was originally included in a presentation I gave at the International Conference on Mobility as a Service (ICoMaaS) in December 2019.

\section{References}

[1] T. Yigitcanlar, M. Foth, and M. Kamruzzaman, "Towards post-anthropocentric cities: Reconceptualizing smart cities to evade urban ecocide," Journal of Urban Technology, vol. 26, no. 2, pp. 147-152, 2019.

[2] R. Mangiaracina, A. Perego, G. Salvadori, and A. Tumino, "A comprehensive view of intelligent transport systems for urban smart mobility,"
International Journal of Logistics Research and Applications, vol. 20, no. 1, pp. 39-52, 2017.

[3] J. Pulkkinen, J. Jussila, A. Partanen, I. Trotskii, and A. Laiho, "Smart Mobility: Services, Platforms and Ecosystems," Technology Innovation Management Review, vol. 9, no. 9, 2019.

[4] S. Sarker, S. Chatterjee, X. Xiao, and A. Elbanna, "The Sociotechnical "Axis of Cohesion" for the IS Discipline: Its Historical Legacy and Its Continued Relevance," MIS Q., vol. 43, no. 3, pp. 695-719, 2019, doi: 10.25300/MISQ/2019/13747.

[5] C. Sørensen, "The Curse of the Smart Machine? Digitalisation and the children of the mainframe," Scand. J. Inf. Syst., vol. 28, no. 2, pp. 57-68, 2016.

[6] M. L. Markus and W. V. Nan, "Theorizing the connections between digital innovations and societal transformation: learning from the case of M-Pesa in Kenya," in Handbook of Digital Innovation, S. Nambisan, K. Lyytinen, and Y. Yoo Eds.: Edward Elgar Publishing, 2020, ch. 4, pp. 64-82.

[7] M. Mocker and N. O. Fonstad, "How AUDI AG is Driving Toward the Sharing Economy," MIS Quarterly Executive, vol. 16, no. 4, pp. 279-293, 2017.

[8] E. Cho and Y. Jung, "Consumers' understanding of autonomous driving," Inf. Technol. People, 2018.

[9] Y. Guo, X. Li, and X. Zeng, "Platform Competition in the Sharing Economy: Understanding How Ride-Hailing Services Influence New Car Purchases," J. Manag. Inf. Syst., vol. 36, no. 4, pp. 1043-1070, 2019.

[10] A. Cheng, M.-S. Pang, and P. Pavlou, "On Intelligent Transportation Systems and Road Congestion," presented at the Thirty Seventh International Conference on Information Systems (ICIS 2016), Dublin, 2016.

[11] K. Ebner, P. Mattes, and S. Smolnik, "Are You Responsible for Traffic Congestion? A Systematic Review of the Socio-technical Perspective of Smart Mobility Services," presented at the 52nd Hawaii International Conference on System Sciences (HICSS 2019), 2019. [Online]. Available: https://hdl.handle.net/10125/59769.

[12] A. Hjalmarsson Jordanius, G. Juell-Skielse, and A. Kailas, "Digital innovation and incubators: A comparative interview study from the perspective of the automotive industry," in Proceedings of the 52nd Hawaii International Conference on System Sciences, 2019.

[13] R. Clarke, R. M. Davison, and W. Jia, "Researcher perspective in the IS discipline: an empirical study of articles in the basket of 8 journals," Inf. Technol. People, vol. 33, no. 6, pp. 1515-1541, 2020, doi: 10.1108/ITP-04-2019-0189.

[14] P. G. Newman and J. R. Kenworthy, Cities and automobile dependence: An international sourcebook. 1989. 
[15] R. Cervero, "Mobility Niches: Jitneys to RoboTaxis," Journal of the American Planning Association, vol. 83, no. 4, pp. 404-412, 2017, doi: 10.1080/01944363.2017.1353433.

[16] J. Urry, "The 'system' of automobility," Theory, Culture \& Society, vol. 21, no. 4-5, pp. 25-39, 2004.

[17] D. Albalate and A. Gragera, "The impact of curbside parking regulations on car ownership," Reg. Sci. Urban Econ., vol. 81, p. 103518, 2020.

[18] G. Mattioli, C. Roberts, J. K. Steinberger, and A. Brown, "The political economy of car dependence: A systems of provision approach," Energy Research \& Social Science, vol. 66, p. 101486, 2020, doi: https://doi.org/10.1016/j.erss.2020.101486.

[19] K. Hymel, "If you build it, they will drive: Measuring induced demand for vehicle travel in urban areas," Transport Policy, vol. 76, pp. 57-66, 2019 , doi: https://doi.org/10.1016/j.tranpol.2018.12.006.

[20] F. Khalaj, D. Pojani, N. Sipe, and J. Corcoran, "Why are cities removing their freeways? A systematic review of the literature," Transport Reviews, pp. 1-24, 2020.

[21] S. Gössling, A. Choi, K. Dekker, and D. Metzler, "The Social Cost of Automobility, Cycling and Walking in the European Union," Ecolog. Econ., vol. 158, pp. 65-74, 2019/04/01/ 2019, doi: https://doi.org/10.1016/j.ecolecon.2018.12.016.

[22] P. Newman and J. Kenworthy, Sustainability and cities: overcoming automobile dependence. Island press, 1999.

[23] P. Newman, L. Kosonen, and J. Kenworthy, "Theory of urban fabrics: Planning the walking, transit/public transport and automobile/motor car cities for reduced car dependency," Town Planning Review, vol. 87, no. 4, pp. 429-458, 2016.

[24] P. Newman, G. Thomson, V. Helminen, L. Kosonen, and E. Terämä, "Sustainable Cities: How Urban Fabrics Theory Can Help Sustainable Development," in "Reports of the Finnish Environment Institute," Finnish Environment Institute, Helsinki, 9521150785, 2019.

[25] M. Ristimäki et al., "Yhdyskuntarakenteen tulevaisuus kaupunkiseuduillaKaupunkikudokset ja vyöhykkeet," Finnish Environmental Institute, 9521146613, 2017.

[26] R. I. Sarker, M. Mailer, and S. K. Sikder, "Walking to a public transport station," Environment, vol. 9, no. 1, pp. 38-53, 2020.

[27] P. Newman and J. Kenworthy, The End of Automobile Dependence. Springer, 2015.

[28] C. Clark, "Transport-maker and breaker of cities," Town Planning Review, vol. 28, no. 4, pp. 237250, 1958

[29] Y. Zahavi and A. Talvitie, Regularities in travel time and money expenditures (no. 750). 1980.

[30] R. Serrano-López, A. Linares-Unamunzaga, and C. Muñoz San Emeterio, "Urban sustainable mobility and planning policies. A Spanish midsized city case," Cities, vol. 95, p. 102356, 2019, doi: https://doi.org/10.1016/j.cities.2019.05.025.

[31] M. Alvesson and K. Sköldberg, Reflexive Methodology: New Vistas for Qualitative Research. London: SAGE, 2018.

[32] M. Alvesson and J. Sandberg, "The problematizing review: A counterpoint to Elsbach and Van Knippenberg's argument for integrative reviews," J. Manage. Stud., vol. 57, no. 6, pp. 1290-1304, 2020.

[33] W. A. Cram, M. Templier, and G. Paré, "(Re)considering the concept of literature review reproducibility," J. Assoc. Inf. Syst., vol. 21, no. 5, pp. 1103-1114, 2020.

[34] T. Greenhalgh, S. Thorne, and K. Malterud, "Time to challenge the spurious hierarchy of systematic over narrative reviews?," European Journal of Clinical Investigation, 2018.

[35] S. K. Boell and D. Cecez-Kecmanovic, "On being 'systematic' in literature reviews in IS," J. Inf. Technol., Debates and Perspectives vol. 30, pp. 161-173, 2015, doi: 10.1057/jit.2014.26.

[36] T. Greenhalgh, J. Raftery, S. Hanney, and M. Glover, "Research impact: a narrative review," BMC medicine, vol. 14, no. 1, p. 78, 2016.

[37] U. Schultze, "Skirting SLR's language trap: reframing the 'systematic' vs 'traditional' literature review opposition as a continuum," $J$. Inf. Technol., Commentary vol. 30, no. 2, pp. 180184, 06//print 2015, doi: 10.1057/jit.2015.10.

[38] M. Alvesson and J. Sandberg, "Generating Research Questions through Problematization," Acad. Manage. Rev., vol. 36, no. 2, pp. 247-271, 2011.

[39] G. Lakoff, The all new don't think of an elephant!: Know your values and frame the debate. Chelsea Green Publishing, 2014.

[40] R. A. Irvin, "How Slogans Curate Public Opinion: Hard Lessons from Lakoff and the Linguists," Public Integrity, vol. 21, no. 4, pp. 433-447, 2019.

[41] A. Carlsen and L. Sandelands, "First passion: Wonder in organizational inquiry," Manag. Learn., vol. 46, no. 4, pp. 373-390, 2014, doi: $10.1177 / 1350507614533756$.

[42] L. Gansky, The Mesh: Why the Future of Business is Sharing. New York: Penguin, 2010.

[43] R. Botsman and R. Rogers, What's mine is yours: how collaborative consumption is changing the way we live. London: Collins, 2011.

[44] F. Bardhi and G. M. Eckhardt, "Access-based consumption: The case of car sharing," J. Cons. Res., vol. 39, no. 4, pp. 881-898, 2012.

[45] T. Slee, What's yours is mine: Against the Sharing Economy. Or Books, 2017.

[46] J. Rifkin, The age of access: The new culture of hypercapitalism. Penguin, 2000.

[47] R. Powell, "Uber boss says the era of car ownership is coming to an end," in The Sydney Morning Herald, ed, 2014. 
[48] A. Shontell, "Uber CEO explains his company's highly ambitious goal to end car ownership in the world," in Business Insider, ed, 2015.

[49] J. Zimmer, "The Third Transportation Revolution: Lyft's Vision for the Next Ten Years and Beyond," in Medium, ed, 2016.

[50] T. Higgins, "The End of Car Ownership," Wall Street Journal, June 20, 2017 2017. [Online]. Available: https://www.wsj.com/articles/the-endof-car-ownership-1498011001.

[51] D. Welch, "GM's Former President Calls for the End of Car Ownership," in Bloomberg, ed, 2019.

[52] C. Mulley, "Mobility as a Services (MaaS) - does it have critical mass?," Transport Reviews, vol. 37, no. 3, pp. 247-251, 2017, doi: 10.1080/01441647.2017.1280932.

[53] G. Smith, J. Sochor, and I. C. M. Karlsson, "Mobility as a Service: Development scenarios and implications for public transport," Research in Transportation Economics, 2018/04/24/ 2018, doi: https://doi.org/10.1016/j.retrec.2018.04.001.

[54] J. Pucher, "Urban public transport subsidies in Western Europe and North America," Transportation Quarterly, vol. 42, no. 3, 1988.

[55] R. Lalive, S. Luechinger, and A. Schmutzler, "Does expanding regional train service reduce air pollution?," J. Environ. Econ. Manage., vol. 92, pp. 744-764, 2018, doi: https://doi.org/10.1016/j.jeem.2017.09.003.

[56] D. A. Hensher, C. Q. Ho, and D. J. Reck, "Mobility as a Service and private car use: evidence from the Sydney MaaS trial," 2020.

[57] K. Huhtala-Jenks, "Minister Berner to meet transport specialists in Helsinki," Finnish Ministry of Transport and Communications, 2015. [Online]. Available: https://www.lvm.fi/en//minister-berner-to-meet-transport-specialists-in$\underline{\text { helsinki-857355 }}$

[58] R. Utriainen and M. Pöllänen, "Review on mobility as a service in scientific publications," Research in Transportation Business \& Management, vol. 27, pp. 15-23, 2018, doi: https://doi.org/10.1016/j.rtbm.2018.10.005.

[59] C. D. Cottrill, "MaaS surveillance: Privacy considerations in mobility as a service," Transportation Research Part A: Policy and Practice, 2019.

[60] C. Whittle, L. Whitmarsh, P. Haggar, P. Morgan, and G. Parkhurst, "User decision-making in transitions to electrified, autonomous, shared or reduced mobility," Transportation Research Part D: Transport and Environment, vol. 71, pp. 302319, 2019, doi: 10.1016/j.trd.2018.12.014.

[61] M. Kamargianni, M. Matyas, W. Li, and J. Muscat, "Londoners' attitudes towards carownership and Mobility-as-a-Service: Impact assessment and opportunities that lie ahead," in "UCL Energy Institute Report, Prepared for Transport for London," MaaSLab, 2018.

[62] T. Storme, J. De Vos, L. De Paepe, and F. Witlox, "Limitations to the car-substitution effect of
MaaS. Findings from a Belgian pilot study," Transportation Research Part A: Policy and Practice, vol. 131, pp. 196-205, 2020, doi: https://doi.org/10.1016/j.tra.2019.09.032.

[63] D. J. Reck and K. W. Axhausen, "How Much of Which Mode?: Using Revealed Preference Data to Design Mobility As a Service Plans," Transportation Research Record, vol. 2674, no. 7, pp. 494-503, 2020, doi: $10.1177 / 0361198120923667$.

[64] Uber, "Form S-1 Registration Statement: Uber Technologies, Inc.," United States Securities and Exchange Commission, April 11, 20192019. [Online]. Available: https://www.sec.gov/Archives/edgar/data/154315 1/000119312519103850/d647752ds1.htm

[65] B. N. Greenwood and S. Wattal, "Show Me the Way to Go Home: An Empirical Investigation of Ride-Sharing and Alcohol Related Motor Vehicle Fatalities," MIS Q., vol. 41, no. 1, pp. 163-188, 2017.

[66] Z. Mi et al., "Cities: The core of climate change mitigation," Journal of Cleaner Production, vol. 207, pp. 582-589, 2019/01/10/ 2019, doi: https://doi.org/10.1016/j.jclepro.2018.10.034.

[67] K. J. Goodwin, "Reconstructing automobility: the making and breaking of modern transportation," Global Environ. Politics, vol. 10, no. 4, pp. 60-78, 2010.

[68] H. Ellis-Petersen, R. Ratcliffe, S. Cowie, J. P. Daniels, and L. Kuo, "'It's positively alpine!': Disbelief in big cities as air pollution falls " in The Guardian, ed, 2020.

[69] F. Manjoo, "I've Seen a Future Without Cars, and It's Amazing," in The New York Times, ed, 2020.

[70] N. Naughton, "Covid-19 Slammed Rental-Car Firms, Then Business Turned Around " in Wall Street Journal, ed, 2020.

[71] D. Nardella, K. Smith, T. Bailleu, M. Dixon, J. Scheffer, and A. Somyurek, "Inquiry into Sustainable Urban Design for New Communities in Outer Suburban Areas," Parliament of Victoria, Melbourne, September 20042004.

[72] J. Moody and J. Zhao, "Travel behavior as a driver of attitude: Car use and car pride in US cities," Transportation Research Part F: Traffic Psychology and Behaviour, vol. 74, pp. 225-236, 2020.

[73] Y. Yoo, "Computing in Everyday Life: A Call for Research on Experiential Computing," MIS Q., Article vol. 34, no. 2, pp. 213-231, 2010.

[74] M. Levy, A. Lanamäki, and R. Hirschheim, "Robust Action Strategies in a Connected but Unequal World: Revisiting American Pragmatism for Social Justice focused Research in Information Systems," Commun. Assoc. Inf. Syst., vol. 47, pp. 113-139, 2020, doi: 10.17705/1CAIS.04706.

[75] G. Walsham, "Are we making a better world with ICTs? Reflections on a future agenda for the IS field," J. Inf. Technol., vol. 27, no. 2, pp. 87-93, 2012, doi: 10.1057/jit.2012.4. 